\title{
Language and Ideology in Texts on Globalization: A Critical Discourse
} Analysis

\author{
Mustafa $\operatorname{Ar}^{1}$ \\ ${ }^{1}$ Department of English language, Ar-Raniry State Islamic University, Aceh, Indonesia \\ Correspondence: Mustafa Ar, Program Studi Bahasa Inggris, UIN Ar-Raniry, Banda Aceh 23111, Indonesia. Tel: \\ 62-651-755-2921. E-mail: mustaryus@gmail.com
}

$\begin{array}{ll}\text { Received: November 25, } 2014 & \text { Accepted: January 4, } 2015 \quad \text { Online Published: March 29, } 2015 \\ \text { doi:10.5539/ijel.v5n2p63 } & \text { URL: http://dx.doi.org/10.5539/ijel.v5n2p63 }\end{array}$

\begin{abstract}
A contentious question in critical language studies has been whether and how ideology is embedded in discourse. This question has attracted attention from scholars within the humanities and social sciences. A number of scholars argue that there is a dialectical relationship between language and ideology. Discourse internalizes and is internalized. By applying Critical Discourse Analysis (CDA) as a transdisciplinary research approach, this paper (re)examines the ideological construction of globalization in two types of genres: newspaper Opinion-Editorial articles and political economic speeches. The paper discusses how discourse and ideology are interconnected in texts on globalization, especially the global economy. As a result of the textual and sociological analysis, the paper identifies two central interrelated ideologies in the discourse of globalization: new capitalism and neoliberalism. These political economic ideologies are construed linguistically through vocabulary and socially through universalization. From a macro sociological perspective, the analysis implies that social-Darwinist survival of the fittest is inevitable in global economic affairs.
\end{abstract}

Keywords: critical discourse analysis, discourse, globalization, global economy, ideology, new capitalism, neoliberalism

\section{Introduction}

Language, or more specifically discourse, is conceived as the most common form of social structure that is closely linked to ideology. Nevertheless, despite the seemingly close relationship between these two aspects, few studies have paid attention to language and ideology in texts on globalization, particularly the global economy. This article concentrates on the relationship between language and globalization because "for better and worse, semiotic systems have become the engines of globalization and of new economies" (Luke, 2002, p. 107). As language has played a more prominent role in the era of globalization (Fairclough, 2002), a number of scholars certainly have addressed the discursive dimension of globalization. However, what is absent in most of these globalization literatures is that the scholars do not theorize and analyze globalization as a form of discourse. If they do, their discussion often lacks textual analysis (Fairclough, 2006).

Critical language studies have focused mostly on the orthodox interactional sociolinguistic analysis that links particular linguistic aspects to social communication (Blomaert, 2005). This approach to text-based analysis has paid more attention to the relationship between language and society rather than how language affects the order of society (Fairclough, 2001). The issues that relate globalization to discourse and the ideological dimension as well as the impact of this phenomenon on social world affairs have received scant attention. Bodies of literature have usually established the relationship between discourse and ideology in the abstract way. Ontologically, many procedures, values, and beliefs of institutions are embedded in the concrete texts and wider contexts of social practices (Fairclough, 2001). Nevertheless, scholars have usually based their analysis of ideology upon discourse theory (Laclau \& Mouffe, 2001) or traditional and abstract exploration of ideology (e.g., Thompson, 1984; Eagleton, 1991; McLellan, 1986). This study attempts to fill in this gap.

The main objective of this paper is to analyze how the discourse of globalization is constructed in Opinion-Editorials (signed newspaper articles) and political speeches and to identify what ideology is embedded in those texts. The theoretical framework for the study is built upon a transdisciplinary approach to globalization (Fairclough, 2003) that comprises the oscillating theories of ideology (van Dijk, 1998), political economy (Jessop, 2004) and theories of discourse as a facet of globalization (Fairclough, 2006) as articulated in the field of Critical 
Discourse Analysis (CDA). The dialogue between these disciplines is established. While the study is aimed at examining the (re)construction of ideology in discourse, ideology is defined as "representations of aspects of the world which contribute to establishing and maintaining relations of power, domination and exploitation" (Fairclough, 2003, p. 218). These representations are always at work in people's ways of enacting and constructing social issues, such as the global economy. To identify the sort of ideology embodied in the globalization texts, in this paper I ask the following specific research questions: What ideology is constructed in the discourse of globalization? How ideology is constructed in the discourse of globalization? What keywords are used in the discursive construction of this ideology?

\section{Theoretical Framework}

One aspect of the study of globalization is the view that language (discourse) is regarded as a facet of globalization, which instills ideology. Fairclough (2006, pp. 26 \& 165) identifies five general claims about discourse as a facet of globalization:

1) Discourse can represent globalization, giving people information about it and contributing to their understanding of it.

2) Discourse can misrepresent and mystify globalization, giving a confusing and misleading impression of it.

3) Discourse can be used rhetorically to project a particular view of globalization which can justify or legitimize the actions, policies or strategies of particular (usually powerful) social agencies and agents.

4) Discourse can contribute to the constitution, dissemination and reproduction of ideologies, which can also be seen as forms of mystification, but have a crucial systemic function in sustaining a particular form of globalization and the (unequal and unjust) power relations which are built into it.

5) Discourse can generate imaginary representations of how the world will be or should be within strategies for change which, if they achieve hegemony, can be operationalized to transform these imaginaries into realities.

Claim point 4 is very much relevant to the theme that has been raised in this paper, because it assists the analysis of ideology discursively inculcated in texts. Other claims such as points 1 and 5 are also relevant, particularly because of their significance to the study of discursive representation in enactment of the discourse of globalization. Yet this paper focuses mainly on the (re)production of ideology in discourse, especially from a Marxist tradition.

Historically, the study of ideology started when French aristocrat Destutt de Tracy who fought as a soldier during the French Revolution proposed a "science of ideas" in his prison cell and called it idéologie (Eagleton, 1991, p. 66). Since then sociologists and linguists alike have defined the term in the field of their interests. According to Gramsci (1971), ideology is "conception of the world that is implicitly manifest in art, in law, in economic activity and the manifestations of individual and collective life" (p. 328). This conception is linguistically theorized by Pêchuex (1982), who asserts that "there is no practice except by and in an ideology" (p.102). Central to this conception is Vološinov's (1973) Marxism and the Philosophy of Language which constitutes a starting point in the study of discourse and ideology. It is "the only work that explicitly seeks to elaborate a Marxist philosophy of language" (Lecercle, 2009, p. 105) and a 'must read' book if a person wants to call himself a practitioner of critical analysis of discourses (Blomaert, 2005). Vološinov's (1973) central thesis is "without signs, there is no ideology" (p. 9). One type of sign is language. The sign possesses meanings, represents, portrays, or stands for something lying outside of itself. A word or an image is a sign, because it has meaning. Whenever a sign is present, ideology is present, for example a hammer and a sickle on the flag of communist party or the word 'liberalize' in the sentence 'governments must liberalize the world trade'. Everything that is ideological possesses semiotic value. Every ideological sign is not only reflection of a reality but it also is a material segment of that reality (Vološinov, 1973). Similarly, Luis Althusser, a Marxist follower, in his celebrated essays Ideology and ideological state apparatuses (1971) also paved the way of 'modern' theory of discourse and ideology. He pointed out that material productions, institutions, apparatuses and so forth could be constituted into social entity through discourse.

This paper, accordingly, regards discourse a particular way of representing the social world and globalization as a socially constructed reality in which discourse can contribute to its construction. For a dialectical and oscillating approach, the paper refers to political economy. This adopted position is derived from the standpoint that economic and political objects are socially constructed and historically specific (Jessop, 2004; Fairclough, 2006). These objects include capital, economic and cultural systems, the role of management and semiosis (discourse). From these constructed objects emerge social relations - the relations between objects and social agents, bringing 
people and their economy as well as culture into interaction. The interactions between social agents and objects involve discourse that enables to represent beliefs and values.

The paper views ideology as a system of ideas, beliefs and values that enact dominance and positions. It further draws from CDA a standpoint that ideology is representations of power, dominance, and legitimation by social groups (van Dijk, 1998; Fairclough, 2003). For example, the new global economy is bound up with transformations of language and ideology in many different ways and social practices by different individuals and agencies (Giddens, 2000). These individuals and agencies include globalization proponents and the financial institutions. The discourse practices are articulated between national and supra-national interests as well as between hybridity and uniformity of practices (Jessop, 2004). Global economy is thus politically determined and embedded in discourse (Fairclough, 2006). It is an ideologically motivated practice of globalization involving discourse which is produced and naturalized by the proponent states, globalist individuals, agencies and organizations (Jessop, 2004). Therefore, if we want to figure out the global economy as a social issue, which is ideologically and politically motivated we can refer to the discursive aspects of that issue by examining concrete forms of texts within which the social 'wrongs' are exposed and represented.

CDA scholars agree that discourse and ideology are contingent (van Dijk, 1998; Fairclough, 2001). Ideologies can be identified in texts. This is because ideology is invested in texts (Zheng, 2014); we cannot "read off ideologies from texts" (Fairclough, 1992, p. 89). Ideology can be used by discourse producers to enact dominance and impose legitimation. One example is the ideology that competition, flexibility and interconnectedness should be imposed if a state wants to survive economically and politically in the era of globalization. One way of promoting and exposing this ideology is through the use of language - discourse, enacted by state leaders in speeches in summits or forums, or by means of articles in newspapers by government think-tanks, leading economists, and policy analysts. The notion that ideologies are cognitively and socially represented in texts stems from the assumption that social interaction takes place within social structures at the widest sense-language, economy and knowledge - and other social systems of classification that includes class (Fairclough, 2003). Ideologies control discourse and other social practices (Fairclough, 2001). For example, the idea that free trade in the global economy should not be restrained by government regulations can be naturalized through genres, such as a political speech or an argumentative newspaper Opinion-Editorial (Op-Ed). Ideological representations thus can be identified in texts, for example by the analysis of vocabulary and propositional contents, among others.

\section{Analytical Framework}

This paper applies CDA to better understand the ideology embedded in globalization texts. CDA allows us to oscillate between the paradigms of explanatory critique (Bhaskar, 1986; Chouliaraki \& Fairclough, 1999) and the linguistic analysis of texts (Fairclough, 2003). The critical analysis of discourse used in this article is, in other words, transdisciplinary. It is linguistic (Fairclough, 2003; Halliday \& Matthiessen, 2014), (cultural) political economy (Jessop, 2004), sociology of globalization (Giddens, 2000).

$\mathrm{CDA}$ is applicable to investigating the relationship between globalization and its ideology, because CDA explores how social events (texts), social practices (orders of discourse), and social structures (language) arise from and are ideologically shared with relations of elements (Fairclough, 2006). This article is thus based on CDA insights that treat discourse as semiotic, inter-subjectivity of meaning, as an irreducible element of all material social processes. We can see social life as interconnected networks of practices of diverse sorts-economic, political, social and cultural domains (Jessop, 2004).

The discourse of globalization is regarded as a network of practices within social life. This paradigm of looking at globalization allows us to investigate the globalization texts both through a visible, textually-oriented analysis and through a social explanation. This is because CDA views language as a moment of social practice, which both constitutes the social world and is constituted by other social practices (Fairclough, 2001). For the textual analysis, I make use systemic functional linguistics (Halliday \& Matthiessen, 2014), especially the lexical grammar. I particularly examine keywords (Fairclough, 2006; Williams, 1983) and their grammatical aspects in the globalization texts. The analysis focuses on the keywords because "The keyword is the fundamental object of the study of ideologies" (Vološinov, 1973, p. 15, italic mine) and vocabulary is the most direct way of constructing and naturalizing ideology (Fairclough, 2001; van Dijk, 1998).

I shall analyze text extracts through a dialogue, that is, an oscillating process that moves back and forth between disciplines, which is based upon transdisciplinarity in its connection to signification and the role of global economic discourse in society. The analytical method applied in the current study is 'labor intensive'; it relies on a limited number of extracts rather than on a larger corpus (millions of words). The extracts which construct ideas, embody beliefs and values pertinent to the discourse of globalization are in the form of clauses, sentences or 
paragraphs. I shall describe, interpret and explain the extracts in terms of the propositional contents, the grammar and meaning of the keywords and their social and political implications. To uncover the social and ideological dimensions, I incorporate the linguistic analysis into the sociological analysis.

\section{Sources of Texts for Data}

This study refers mainly to two countries for the research site and the sources of texts: the USA and China. This consideration is drawn from the principle that globalization cannot be discussed effectively without making references to specific locations and places. The sources of texts come from two types of genres: newspaper OP-Ed articles and speeches on globalization, particularly global economy. The two modes of genre are chosen to avoid the privilege of one text type over the other.

The Op-Ed articles come from the Washington Post and China Daily. The Washington Post is chosen because its position on economic issues is of a definitively conservative stance; it advocates free trade agreements. The speeches for the U.S. data were chosen from the remarks of Ben Bernanke and Frederic Mishkin and the speeches by President George W. Bush and Barack Obama. These texts were retrieved from http://www.washingtonpost.com/, http://www.whitehouse.gov/ and http://www.federalreserve.gov/.

I choose the China Daily, because it is the most widely circulated newspaper among the majority of Western readers and the most frequently quoted China newspaper by international news media. The China Daily is committed to helping the world know more about China and the country's integration with the international community. The newspaper is often called the "Window to China". This is because the China Daily "plays an important role in creating China's national images and articulating the Chinese government's politics and foreign policy concerns and priorities to the international community" (Li, 2009, p. 87). For the China's context, I also choose the political economic speeches that were delivered by Wen Jiabao and Zeng Peiyan. I choose the speeches of Prime Minister Wen Jiaboa and Vice Premier Zeng Peiyan, because they used to represent China in most of the international economic agendas, for example at the World Economic Forum (WEF) Annual Meetings. Wen Jiabao and Zeng Peiyan delivered the speeches in Chinese, but this study refers to the English version of the speeches which were authoritatively prepared by the government of China. The texts on globalization, especially the global economy from China's perspectives were retrieved from http://www.chinadaily.com.cn/ and the China government's English website http://www.english.gov.cn/.

The texts were collected by browsing the sites, using the keywords 'globalization', 'global economy', and 'world economy', appearing in the title or in texts. Six Op-Ed articles and eight speeches were selected. The texts altogether consist of 30.969 words. The study refers only to texts that have been made available online between 2005 and 2011. I choose this period because it was the reemerging epoch of globalization debates. Although the pervasive debate of globalization was unleashed since 1980s, the discourse of global economy reached the peak after the late 1990s Asia's financial crisis and was once again in a serious debate at the beginning of the $21^{\text {st }}$ century when the global financial crisis emerged in 2008.

For the analytical convention of extracts, the contextual clues deemed relevant to the theme of discussion are underlined. Numbers in square bracket [para. 0] specify paragraph. Bracketed dots (...) indicate omissions. Single 'quote' indicates that the linguistic elements referred to are from the extracts or texts.

\section{The Data and Analysis of Extracts}

The discursive construction of globalization in the two text types is not ideology-free. The discourse of globalization constructs new capitalism and neoliberalism. The discursive construction of these ideologies can be generated from the uses of 'keywords' (Fairclough, 2006; Williams, 1983), their derivatives and grammar. The typical keywords that are enacted in the discourse include: 'competing' in the global economy; 'free market' capitalism; and global economic 'development', among others. The keywords are set out in the table below.

Table 1 . The 15 keywords and the number of their occurrences in the globalization texts

\begin{tabular}{lll}
\hline Word & Occurrences & Percentage $(\%)$ \\
\hline development & 190 & 0.61 \\
growth & 120 & 0.38 \\
international & 87 & 0.28 \\
reform & 75 & 0.24 \\
open & 72 & 0.23 \\
investment & 67 & 0.21 \\
capital & 55 & 0.17 \\
\hline
\end{tabular}




\begin{tabular}{lll}
\hline change/exchange & 49 & 0.15 \\
liberalization & 32 & 0.10 \\
labor & 29 & 0.093 \\
management & 26 & 0.083 \\
competition & 25 & 0.080 \\
technology & 25 & 0.080 \\
free + market / free + trade & 23 & 0.074 \\
communication/telecommunication & 12 & 0.038 \\
\hline
\end{tabular}

Table 1 above shows us the frequency of 15 keywords occurring in 30.969 word database of the globalization texts. References will be made to these typical keywords at the point they are relevant to the topic of discussion.

The table shows that the item 'development' is the most common keyword; its synonym 'growth' ranks the second. The item 'development' is used in a broad economic context, meaning the application of human, financial and natural resources to satisfy human needs and well-being; thus, 'social development', 'economic development', 'financial development', 'market development', 'industrial development', 'institutional development' and 'technological development'. The item is used in terms of the Keynesian sense, that is, the economic transformation of a country that leads to the improvement of the well-being and economic capabilities of its citizens. Meanwhile, the lexical item 'communication/telecommunication' is the fewest. It theoretically refers to means of passing information through the media (Williams, 1983). Nevertheless, this item plays a significant role in the discursive construction of ideology (to be discussed in detail in Subsection 5.1.1). Other lexical items, such as 'competition' and 'free market' are less frequent than the item 'development', but those items are also politically conditioned in the discourse of global economy (Fairclough, 2006). The items 'competition', 'free market', 'technological transfer', and 'trade liberalization' are discursively used in the realism of ideological (re)construction. We now turn to this topic.

\subsection{New Capitalism}

New capitalism and its trajectories are textually embedded in the discourse of globalization in Op-Eds and political speeches. New capitalism is internalized through signification of global 'communication', advances in 'technology', 'global competition' and 'management'. New capitalism is the emergent form of capitalism that includes the information society and knowledge-based economy.

\subsubsection{New Capitalism and Advances of Technology}

New capitalism can be characterized by the practices of competition and advances in technology. Global capitalism in addition to controlling its economic ideology is also dominant in the technology mastery. The system of capitalist global economy allows its practical actors to encourage the growth of global trade relations with help provided by advances in technology and transportation, for example, air freight and shipping. This change of operation has transformed capitalism into new capitalism. The technology-oriented capitalism is evidenced in its discursive construction.

(1) I just had a chance to see some of the high-tech steam turbines and all kinds of fancy stuff that's being made here, being manufactured here at this plant. (...), because GE has been producing turbines and generators here in Schenectady for more than a century [para. 4].

We've seen technologies transform the ways we work and the ways we communicate with one another. (...) We've seen our economy transformed by rising competition from around the globe [para. 5]. (...)

All of you represent people who each and every day are pioneering the technologies and discoveries that not only improve our lives, but they drive our economy [para.6]. (...)

So we know we can compete. Not just in the industries of the past, but also in the industries of the future [para. 12]. (...)

For America to compete around the world, we need to export more goods around the world. That's where the customers are. It's that simple [para. 13]. (...)

Our job is to do everything we can to ensure that businesses can take root and folks can find good jobs and America is leading the global competition that will determine our success in the $21^{\text {st }}$ century [para. 28]. (...)

So ultimately winning this global competition comes down to living up to the promise of places like this [para. 34]. (Barrack Obama, January 21, 2011) 
(2) Globalization is leading to the integration of the world's markets, culture, technology, and governance, in a similar way to the spread of communications, trade, transport and technology in Genghis Khan's era. (China Daily, June 06, 2006, para. 5)

(3) We encourage our enterprises to upgrade technologies and make technological renovation. We support them in making extensive use of new technologies, techniques, equipment and materials to restructure their product mix, develop marketable products and improve their competitiveness. (Wen Jiabao, January 28, 2009, para. 5)

(4) The good that globalization has done is hard to dispute. Trade-driven economic growth and technology transfer have alleviated much human misery. (Washington Post, July 16, 2008, para. 4)

The extracts (1), (3) and (4) above demonstrate that technology and competition are economically related in the social and material processes of the global economy. Grammatically, the item 'technology' collocates with 'transform', 'pioneer, 'improve' and 'transfer' and the item 'competition' collocates with 'global', 'the world', and 'improve'. Linguistically, 'technology' is countable; therefore it can be pluralized 'upgrade technologies' and 'extensive use of new technologies'. Politically, technology is transferable, that is, the transfer of technologies from countries where they are more advanced to countries where they are less advanced. Technological transfers are part of undeniable 'gains from globalization.' In social reality, however, like capital, technology does not move where it is more sophisticated to a location where it is financially not promising (Kiely, 2000).

The extracts indicate that technologies not only socially 'transform the ways we work and the ways we communicate with one another' but they also economically 'improve our lives' since they 'drive our economy' and 'alleviate much human misery'. The discourse also manifests technology centers, such as Silicon Valley that contributes to a new economy and industrial strength. Giant companies such as the General Electric and Silicon Valley have traditionally been able to manufacture sophisticated goods 'the high-tech steam turbines' and 'generators' (1) due to pioneering technology. Advances of technology have enabled activities in globalization to achieve their goals such as 'economic growth'. This reality is indisputable. In fact, globalization per se has driven the spread of technology since Genghis Khan's era (2). As a result, technologies should always be 'upgraded', and made use of them for the sake developing economic growth. The globalists see technologies only from the positive contribution they make for the people who can afford them.

The breakthroughs of technology especially when they achieve their 'intellectual property rights' are not always good for the sake of generic human progress, not as said 'technologies transform the ways we work and the ways we communicate with one another.' The 'we' in this context is the "monopolistic we", not 'we' for the general public. For example, since advances in pharmaceutical technologies emerged, the secret of traditional Indian medicines producers who have relied on tree leaves for two centuries has been confiscated by the U.S. pharmaceutical companies through the WTO's regularized law, leaving the indigenous Indian populations unable to profit from the knowledge they have developed over centuries (Wallach \& Sforza, 1999). The pharmaceutical technology has a bad impact on the traditional medicine.

The worth that technology has contributed to human progress amid globalization is of course hard to dispute (4). But the fact that the advantage of technological advances is selective is disputable. It is argued that advances in communication technologies have expanded economic activities such as 'trade', but communication technologies are not always affordable to every part of the planet. Technologies benefit more industrial countries than the less developed countries (LDCs); for example, see Kiely (2000) and Blomaert (2005) for the presentation of two African LDCs in getting access to communication technology and electricity. Communication technologies are selective as they do not apply the same rate. For example, when you make a call from Sydney to Jakarta, the telecommunication cost is more expensive than when you make a call from Sydney to London, despite the fact that Jakarta is much closer to Sydney. The rate is different because globalization has divided the planet into the nations' historical reasons and political interests, and is not based on the geographical space. The cost of a call from Sydney to London is less expensive because Australia is part of the Commonwealth, while Indonesia is not. Telecommunication technology thus has economically and politically benefited more certain locations of the planet than others (Kiely, 2000).

The extracts show that global capitalist can make use of producing plants, such as 'General Electric' and 'Silicon Valley' as well as communication facilities and other advances in technology to dominate system of productions and distributions as the workers are 'pioneering technologies'. As a result, giant corporations, for example the U.S.-based Microsoft, South Korea-based Samsung, and Japan-based Nippon, can manufacture products in unlimited quantities and sell them in a wide range and distance. Consumers around the planet can buy "the same goods at the same time" (Scholte, 1997, p. 434). Unfortunately, the profits gained from the products mostly return to the capitalist countries where the property rights owners are headquartered, not to the "Third World" 
countries where goods are manufactured (Chang, 2011). Even though the developing countries where the products are made and sold gain revenue, the source countries gain profits. Therefore, the distribution of wealth is still the same. This is where the global capitalist political economy is really functioning and divides the world economically and politically.

Using sophisticated technology, global capitalist actors can manufacture large amounts of goods with lower costs. If the manufacturers have to hire 'labor force', they will attempt to do it with a low cost even though they can afford it with higher costs. As a result, two associated companies, one in the USA and the other in China can obtain 'labor' with a considerably different wage. For instance, when an American worker receives US\$10,000 per year in an American firm in the USA, a Chinese worker will make US\$ 1000 a year working at the same associated American firm in China (Chang, 2011). This is a reason that foreign companies invest in countries that have lower wages for labor force.

(5) First, opening financial markets to foreign capital directly increases access to capital. (...) We know that labor is cheap in poor countries, and so we might think that capital would be especially productive there. Just think of how hugely profitable a factory might be in a country where wages are one-tenth of those in the United States (...). Such capital flows could lead to substantial benefits for poor countries in the form of larger capital stocks, higher productivity, and more rapidly growing incomes (Frederic Mishkin, April 26, 2007, para. 18)

(6) With 30 years' of reform and opening-up, we have laid a good material, technological and institutional foundation. We have a large well-trained and relatively low-cost labor force. (Wen Jiabao, January 28, 2009, para. 7).

(7) For a country like China with 1.3 billion people, without a certain rate of economic growth, full employment and people's well-being can only be empty talk [para. 2]. (...)

China's huge market volume (...) and fair market environment are attracting more and more multinational enterprises to invest and establish business in China. China is now one of the world's largest foreign investment destinations. More than 470 of the top 500 global companies have established their presence in China [para. 14]. (Wen Jiabao, September 13, 2010)

(8) We will adjust income distribution, ensure that personal income grows in step with economic growth and that labor remuneration grows in step with increase of productivity. (Wen Jiabao, September 14, 2011, para. 13).

Extract (5) 'we know that labor is cheap in poor countries' constitutes the global capitalist statement of fact. Labor is seen as a commodity like oil; the cheaper, the better. Likewise, as a country with a population of ' 1.3 billion people' (7), it can be assumed that China has a very accessible labor force (we should be cognizant of Jiabao's intention) and 'relatively low-cost' (6), but it can be inferred from 'labor remuneration grows in step with increase of productivity' (8) that labor wages will not be costly there. This is a reason why 'More than 470 of the top 500 global companies have established their presence in China' (7). The situation like this might be an indication of how low wages have triggered suicides among the workers laboring in the global companies in China. The global media such as the CNN and Al Jazeera covered this sad news in May of 2011. But this sort of issues is rarely raised in the global economic texts.

Global investors usually spend their capital including technologies of production in the regions where wages are low, especially 'in poor countries' but where market is large, so that they can exploit laboring as they need it. By means of technology and labor force they can produce large amount of goods in an efficient time and sell their products there as well. As a result, foreign investors obtain the high returns. This is why Naomi Klein, the opponent of globalist discourse, in her book No Logo (1999) belittles the logic of global capitalism that justifies the unethical manner of multinational corporations in exploiting 'Third World' workers for the sake of profit-making and a victory for the neoliberal globalization agenda has become "a self-fulfilling prophecy" (Kiely, 2000, p. 1064). Technology has alleviated the process of production and taken over labor work. As a result, even the cheap labor forces are victimized.

As it is true for the role of technology, communication also plays a crucial role in manifesting new capitalism (Fairclough, 2002). The extracts below together with (2) above provide further illustrations that the genres and discourse of the globalization make references to 'communication' as a social material process that contributes to manifestation of globalization.

(9) But our estimates of future policy liberalization alone (excluding likely benefits from better communications and transportation) indicate that a move from today's commercial environment to global free trade and 
investment could produce an additional $\$ 500$ billion in US income annually, or roughly $\$ 5,000$ per household each year. (Washington Post, June 07, 2005, para. 6)

(10) In addition, international supply chains, made possible by advances in communication and transportation, reduce costs and increase the competitiveness of U.S. firms [para. 10]. (...)

Offshoring has been driven by several factors, including improvements in international communication, the computerization and digitization of some business services, (...) [para. 19]. (Ben Bernanke, May 1, 2007)

The lexical item 'communication' cannot escape itself from the language of new capitalism. This can be said so, because "today, communication is a key sector of advanced capitalism" (Lecercle, 2009, p. 65); communication manifests 'international supply chains' (10). As it implies, the term communication as in 'better communication' (9) seems to have been used in the extracts to mean the transmission or exchange of information, messages or data from one individual or group to another. Socially, people communicate to achieve the planned goals of interactional processes, such as obtaining or controlling economic practices within a social system. Historically, in the eighteenth century, the word 'communication' was used as an abstract general term, referring to physical facilities, such as roads, canals, and railways (Williams, 1983). But today the term communication is used even to refer to means of passing information, including 'the computerization and digitization' that 'reduce costs and increase the competitiveness'. Extract (10) shows that communication can politically and socially be scaled 'international communication'. 'International communication' is used in a political sense, in a similar political context of free trade (Subsection 5.2 below), for example the international satellite, the international space station, in which just because the process of communication involves two powerful rich countries, it is called 'international'.

The discourse implies that communication plays an important role in making the world as a global village. Thus from a transdisciplinary standpoint, language has played a central role in a new capitalist system, because "the system is information-based, depending on communication technologies" (Fairclough 2002, p. 163). The salient role of language in global capitalism is taken for granted by media corporations. Global communication is seen as the integration process of every individual and group around the earth into a gigantic network mediated by information infrastructure, e.g., the $B B C$ and China Daily. People in this globalization age can refer to global communication channels for miscellaneous issues-from stock exchanges to everlasting conflicts (Palestine and Israel).

The global economic discourse is employed to generalize and naturalize ideas, policies, strategies and progresses of social material processes of globalization in genres and discourses. This discursive construction is part of the globalist shared consciousness. The following extracts together with (2) and (4) above provide examples that capitalist globalization is claimed to have played a crucial role in creating people's well-being.

(11) If we resist protectionism and isolationism while working to increase the skills and adaptability of our labor force, the forces of globalization and trade will continue to make our economy stronger and our citizens more prosperous. (Ben Bernanke, May 1, 2007, para. 30)

(12) Globalization brings more efficient use of scarce resources, a greater and cheaper range of goods and services, reduced poverty, faster economic growth and rising living standards. (China Daily, May 20, 2011, para. 14)

(13) Our confidence also comes from the fact that the advantages contributing to China's economic growth remain unchanged. With 30 years' of reform and opening-up, we have laid a good material, technological and institutional foundation. We have a large well-trained and relatively low-cost labor force. (Wen Jiabao, January 28, 2009, para. 7).

The propositions in the extracts are of the globalist stance in that 'protectionism', 'adaptability of our labor force', 'trade' and 'faster economic growth' are discursively constructed to play an essential role in manifesting globalization. This is because, globalization is claimed to have to make 'our economy stronger and our citizens more prosperous', 'reduced poverty', created 'faster economic growth' and raised 'living standards'. The claim is actually motivated by such an assumption that the progress of advanced nations presumes a smoothly operating global economy. Globalization produces not only physically damaging risks (e.g., environmental damage) but also socio-economic risks, the widening economic gap between rich and poor ramping across nations (Fairclough, 2006). However, this issue has passed the attention from the free market ideologists.

The progress of specific nations is universalized as the success of the global economy. It is argued that globalization has transformed aspects of social life 'markets, culture, technology, and governance' and the widening of 'communications, trade, transport and technology' (2) without taking dominance of those nations into 
account. This is because the aspiration of capitalist political economy is measured by technological advances, cross-border trade and capital flows.

The extracts indicate that different from old capitalism which was practiced in terms of private ownerships of firms, land, and machinery, new capitalism operates on limited-liability corporations, stock exchanges 'the world's markets', 'intellectual property rights', 'telecommunication' and the like inspired by the application of technological innovations. All these resources of the practices within new capitalism focus on "earning money by money" therefore the 'integration of the world's markets' (2) rather than "earning money by bones", using sickles as still continuously practiced by blue colors and peasants in villages in many parts of the globe. The majority of the world citizens specifically in the "Third World" have to earn their living by bones because they do not have the required financial capacity or corporations to compete in the global economy. Or they have to work for private owners of production and distributions as in 'We have a large well-trained and relatively low-cost labor force' (13), where there is a possibility of exploitation. What 'labor force' owns is bio-power — physical strength — and not 'the world market' or 'more cross-border trade'; what peasants mostly own is a pair of gloves, a sickle or a hammer as it is symbolized in the flag of the Communist Party of China.

For the last two decades or so new capitalism has even transformed its operational strategies from capital measures to the role of management expertise in the global economy.

\subsubsection{New Capitalism and Management Discourse}

Management has played a more crucial role in capitalism. It gives rise to new capitalism and simultaneously has become a vehicle of new capitalism (Chiapelo \& Fairclough, 2002). Genres and discourses on the global economy manifest management as a trajectory of capitalism. The management expertise contributes to a successful economic practice in modern capitalism. The extracts below are concerned with the importance of the contribution of management in exercising new capitalism even during the global financial crisis.

(14) No matter how efficient a plant might be, it would be hugely wasteful if raw materials did not arrive on time or if the output couldn't be quickly distributed and sold. Managers were essential; so were statistical controls. Coordination and organization mattered. Companies that surmounted these problems succeeded [para. 6]. (..)

The rise of big business involved more than tycoons. Its central feature was actually the creation of professional managers. Like many great truths, this one seems obvious after someone has pointed it out [para. 7]. (Washington Post, October 26, 2006)

(15) Silicon Valley is about a culture of risk-taking, not just by companies and investors, but workers as well. It's about companies where everyone understands that the way to get rich is to make great products that change the world. And it's about management that eschews bureaucracy, that values talent above all else, (...) and inspiration to flow from the bottom up rather than the top down. (Washington Post, February 27, 2008, para. 13)

(16) Because of outdated regulatory structures and poor risk management practices, many financial institutions in America and Europe were too highly leveraged [para. 10]. (...)

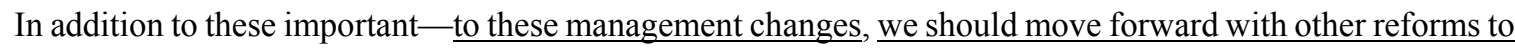
make the IMF and World Bank more transparent, accountable, and effective [para. 22]. (George Bush, November 13, 2008)

(17) In terms of the major tasks of our reform, we need to promote the reform of the administrative system, and accelerate government restructuring to strengthen government capacity of social management and public services. (...) Second, we will actively and effectively use foreign investment and improve the quality of FDI utilization, laying emphasis on introducing advanced technologies, managerial expertise and high-caliber professionals. (Zeng Peiyan, January 25, 2006, para. 12)

(18) What's important is to keep those negative impacts within a scope that we can manage [para. 4]. (...)

We will make all-round efforts to save energy, water, land and materials and make comprehensive use of all kinds of resources, enhance the conservation and management of all natural resources, and take a holistic approach to protect and repair the eco-environment [para. 10]. (Wen Jiabao, September 13, 2010)

The extracts above demonstrate the construal of globalization from the management worldview. Textually, the item 'management' can come together with 'bureaucracy' (15), and 'changes' (16). Economically, the discourse of new capitalism concentrates on management because it is management that actually counts in the successful globalization. In the past, 'Managers were essential' (14). But now time has changed. Management has to be 
remodeled because it is part of the social change that needs to be adopted. Globalists now need the management that avoids 'bureaucracy' and that moves 'the bottom up rather than the top down'. This sort of management is exampled by giant corporations such as Silicon Valley (15). The new management covers all economic, political, and social aspects from the financial crisis to 'natural resources' (18). The management enables social agents to control social risks through 'a culture of risk-taking' (15). The new management model has to be implemented even for the giant financial institutions, the IMF and the World Bank, because these institutions are presupposed to be no longer suitable for the contemporary economic development.

The propositions of the extracts are in line with what the high level managers advise on-job managers or those who are in training that they see management as the core priority in organizations. The management 'guru' Kenichi Ohmae in his The Borderless World (1994) is one example. Management is seen as the sophisticated skill in manipulating significant changes in trade, finance and 'governance'. The managers should be capable of turning the imagined, the beliefs, into institutional forms and material processes (Fairclough \& Thomas, 2004; Chiapelo \& Fairclough, 2002). The free market mechanisms of the global capitalism that include competitiveness and capital flows are all have to be steered by both 'advanced technologies' and 'managerial expertise.' To achieve that end, companies therefore must be able to adapt to and transform the market in accordance with the preference of time and space (Giddens, 2000). This task can be implemented only by 'professional managers' (14) and 'high-caliber professionals' (17). Managers are seen as high rank human capitals that must be able control the companies' affiliates, labor force, and materials. Although natural resources are abundant, labor is intensive, and the technologies are capable of producing large amounts of products in a short time, the companies will not gain profits 'if raw materials do not arrive on time or if the output cannot be quickly distributed and sold' (14). To that end, corporations are in need of superb management.

New capitalism also seems to have taken for granted the breakthroughs of information technology for its development. Rather than relying on the fax-machine, conventional telephone connection, the management of new capitalism has prioritized the contribution of the internet and social networking, for example for advertising and selling the products. The producing giants not only invent these devices, but also sell and make use of them. We now turn to the role of knowledge economy in new capitalism.

\subsubsection{New Capitalism, E-culture and Knowledge-based Economy}

Technological information and knowledge-based economy have also contributed to the development of capitalism to new capitalism. The following extracts show us how the new capitalist economy refers to information technology and knowledge-based economy as the fundamental aspects in transforming the way people work and dominating industries in the era of global market:

(19) It's also true that old, established firms — despite ample capital and technical know-how —often don't dominate new industries. Google, eBay and Yahoo rule the Internet, not General Motors, Sears or Disney [para. 9]. (...)

Chandler admits as much. Asked about how the corporation might evolve, he confesses ignorance: "All I know is that the commercializing of the Internet is transforming the world". To fill that void, someone must do for capitalism's next stage what Chandler did for the last [para. 11]. (Washington Post, October 26, 2006)

(20) Today, in a world of container ships, jumbo jets, and the Internet, goods and many services are delivered faster and more cheaply (in inflation-adjusted terms) than ever before [para. 1]. (...)

But because farming and medicine require special knowledge and skills, a far more efficient arrangement is for the farmer to specialize in growing food and for the doctor to specialize in treating patients. Through the specialization made possible by trade, the farmer can benefit from the doctor's medical knowledge and the doctor can enjoy lunch [para. 3]. (...)

Patterns of trade are determined by variations in a number of factors, including (...) the skills and knowledge of the population [para. 5]. (...)

Offshoring has been driven by several factors, including (...) the computerization and digitization of some business services, and the existence of educated, often English-speaking workers abroad who will perform the same services for less pay [para. 19]. (...)

Moreover, in many fields, closeness to customers and knowledge of local conditions are also of great importance [para. 20]. (...) 
Importantly, workforce skills can be improved not only through K-12 education, college, and graduate work but also through (...) on-the-job training, (...) and online training [para. 26]. (Ben Bernanke, May 1, 2007)

(21) It is what allowed entrepreneurs in Silicon Valley to change the way the world sells products and searches for information. It's what transformed America from a rugged frontier to the greatest economic power in history - a nation that gave the world the steamboat and the airplane, the computer and the CAT scan, the Internet and the iPod. (George Bush, November 13, 2008, para. 28)

(22) This, in turn, has fully activated factors such as labor, capital, knowledge, technology and management, which form the source of rapidly increasing social wealth [para. 5]. (...)

We will vigorously develop strategic emerging industries, (...), new-generation information technology, biotechnology, high-end equipment manufacturing, new energy, new materials and new energy vehicles [para. 11]. (Wen Jiabao, September 14, 2011)

The extracts show that today giant companies such as 'Silicon Valley', 'Google', 'eBay' and Yahoo' that work by means of the capitalist principles (competition in research and innovation) make use of cyber technology 'the Internet' and 'the computerization and digitization of some business services' as a way of dominating the economy. This new paradigm of dominating the global economy is theoretically justified by academia (e.g., Kanter, 2001; Charlesworth, 2014) and is politically constructed in discourse by leading economists (e.g., Ben Bernanke \& Frederic Mishkin), politicians (e.g., George Bush \& Wen Jiabao), and socially mediated by newspaper columnists (e.g., Robert Samuelson as in (19) of the Washington Post).

The breakthroughs of information technology are properly relevant to the dominant economies, such as the USA and its global corporations, for instance 'Google, eBay and Yahoo' that 'rule the Internet' and 'not General Motors, Sears or Disney' (19). The negation 'not' signifies the development of old capitalism 'General Motors, Sears or Disney' to new capitalism 'Google, eBay and Yahoo' which are in control of the global economy. The internet contributes to 'faster' and 'more cheaply' delivery of 'goods and services' (20). For China's economic strategy, a similar paradigm applies as in 'with the support of innovation, China 'will vigorously develop strategic emerging industries ... new-generation information technology' (22). China has been moving to a new economy, hence, 'new-generation information technology'. This happens because, as it is optimistically said, the 'internet is transforming the world' (19), that is, the 'world' for new space and time (Fairclough, 2006); the world without borders (Ohmae, 1994). This transformation includes changes the way people commercialize 'goods' and 'many services' and even in preparing 'workforce skills' by means of 'on-line training'. What the discourse embeds here is that the breakthroughs in information technologies are seen from a market perspective. Economic activities such as 'commercializing' accordingly colonize other social interests, such as disseminating information.

Engagement in the digital world is now regarded as a requirement for successful participation in society. In the domain of management, scholars have seen the internet as a necessity. A management guru (Kanter, 2001; see also Subsection 5.1.2 above) prescribes that companies that are successful on the web are guaranteed to operate differently from their laggard counterparts (cited in Fairclough, 2003). Economically speaking, the internet helps producers sell their products anywhere around the world 'faster and more cheaply' (20), but politically it is generally 'Google, eBay and Yahoo' that rule the internet (19). It is true to say that in present days, these web providers have replaced the way people shop from the conventional transaction (coming to the shops) to modern transaction (using internet) and unsurprisingly it does not matter whether one buys a frying pan or a diamond ring. It is even truer to say that these internet giants dominate the information technology industry.

The eminent success in the way people communicate in doing businesses in the contemporary world is not always advantageous to any business in society in all parts of the globe. This is because from a global economic perspective, it is the best products that dominate the market. Web-page transactions are more helpful for giants, but at the same time they belittle micro home industries that do not have capital to get access to such communication technologies. Communication experts agree that advances in information technology such as the internet has transformed corporations, financial institutions, and business people to interact in an efficient way. This is because globalization has been seen as a process driven by increasing technological scale and information flows. The information technology has made the world borderless (Ohmae, 1994; Giddens, 2000). But simultaneously unfair globalization through its information technology has turned the borderless world into parts, the producing countries and the consuming countries.

Altogether, the extracts also demonstrate that the global economy is now organized around the production and possession of immaterial symbolic objects, that is, 'knowledge' and 'skills' as commodities facilitated by new information and communication technologies. The economic resources as 'capital', 'informational technology', 
'biotechnology', 'innovation', 'management' and 'knowledge' are inseparable entities in manifest new capitalism. Knowledge is a resource for 'rapidly increasing social wealth.' Knowledge is treated similar to 'capital', hence, 'social wealth'. A farmer or doctor needs to rely on specialized knowledge for economic interaction (20). They need each other economically. Their 'special knowledge' determines the 'patterns of trade'. Knowledge is a commodity for trade. This indicates that new capitalism is characterized by knowledge-based economy (KBE), which comprises capital, informational technology, innovation and the internet (Jessop, 2004).

From a free market business perspective, the advantage of internet and knowledge in the global economy is undeniable. In the e-culture survey for her book Evole! Kanter (2001) found that the companies that use the internet tend to have flexible, empowering and collaborative organizations. She contends that the companies that are laggard in e-culture have difficulties in collaboration despite their hard work. Kanter (2001) further prescribes that companies in the e-culture globalization must create communities that are guided by the integrated purpose. This is because, she argues, web-based communities work more successfully than bureaucracy. According to Kanter, decisions in companies should not be made by those who have higher ranks but by those who have more knowledge; therefore, today KBE community is controlling the economy.

The e-culture managers who know how to manage themselves will have their companies provide self-help resources. For these managers, network companies, the internet, global finance, and varying productions constitute forms of capital accumulation process. As implied in (19), companies today cannot rely entirely on professional managers without taking into account the managers' knowledge of the e-culture, the internet. Different from most roundtable-oriented management, in e-culture management decisions are not made by authoritarian chiefs in a meeting, but they can be made by those who have competencies and the decisions can be made in "exile". With the help provided by 'the information technology', the planet is now rescaled in a compressed system of space and time, a shrinking of the world, which is inspired by "the intensification of consciousness of the world as a whole" (Robertson, 1992, p. 8), as if the informational aspects of the global economy were a unit in real time on a planetary scale.

The extracts discursively construct the mindsets concerning information technology, the internet, and knowledge in relation to the free market economy deriving from the social beliefs and practices of the new capitalist political stance. But the practices need to be shared between the people who have already had the access to modern expensive information technology and those who have not, unless social critics will keep speaking for them until an alternative globalization is implemented (e.g., Kiely, 2000; Amin, 1997).

\subsection{Neoliberalism}

Neoliberalism is conceived as a political project that attempts to remove trade barriers and other obstacles such as welfare programs in order to develop into full new capitalism. Neoliberal economy and its modus operandi are enacted to attain the full progress of new capitalism (Bourdieu \& Wacquant, 2001; Fairclough, 2002). Neoliberalism is materialization of a political, social and economic agenda that is promoted as a tenet by the WTO, the IMF, and the Word Bank. The ideology of neoliberalism is embedded in the texts on globalization and is characterized by the discourse of 'free market', 'trade liberalization', 'opening-up', deregulation of market and 'reforms' of economic and political strategies. This feature of discursive construction is manifested in Op-Eds in mass media and in political speeches at a number of social economic events, such as economic conferences and the WEF Annual Meetings.

(23) There is no question that trade liberalization creates winners and losers. (...) [para. 1].

But Congress should consider how freer trade affects the nation as a whole. Since World War II the United States has led the international quest to liberalize world trade and investment. (...) After a half-century of steady liberalization it is fair to ask, what do Americans have to show? [para. 2].

Unfortunately for the cause of continued liberalization, Americans do not receive this money as a check marked "payoff from globalization." [para. 4]. (...)

The benefits of trade and investment liberalization are positive and large. (...) Despite the huge payoff to the United States, maintaining political support for trade liberalization has never been easy [para. 5]. (Washington Post, June 07, 2005)

(24) Restricting trade by imposing tariffs, quotas, or other barriers is exactly the wrong thing to do. (...) Working through the World Trade Organization or in other venues, we should continue to advocate the elimination of trade distortions and barriers in our trading partners even as we increase the openness of our own economy. We should also work to ensure that both we and our trading partners live up to existing agreements under the World Trade Organization (Ben Bernanke, May 1, 2007, para. 24). 
(25) History has shown that the greater threat to economic prosperity is not too little government involvement in the market, it is too much government involvement in the market. (...) When nations open their markets to trade and investment, their businesses and farmers and workers find new buyers for their products. (...) Thanks in large part to open markets, (...) [para. 24].

While reforms in the financial sector are essential, the long-term solution to today's problems is sustained economic growth. And the surest path to that growth is free markets and free people. (Applause.) [para. 25].

But the crisis was not a failure of the free market system. And the answer is not to try to reinvent that system. It is to fix the problems we face, make the reforms we need, and move forward with the free market principles (...). [para. 26]. (George Bush, November 13, 2008)

(26) Since its accession to the World Trade Organization more than four years ago, China has (...) gradually cut tariffs, removed mom-tariff measures, liberalized trade in service, pushed forward a new round of multilateral trade talks in an effort to create a favorable environment for further expanding international economic and technical exchanges and cooperation [para. 3]. (...)

China follows an opening-up strategy that promotes mutual benefit. We are ready to work with the international community to expand two-way market access, improve the multilateral trade system and advance trade and investment liberalization and facilitation so as to create a better environment for trade and economic cooperation [para. 14]. (Zeng Peiyan, January 25, 2006)

(27) The first decade of this century has seen major changes in the global political and economic landscape. (...) Great progress has been made in China's comprehensive reform, opening-up and modernization endeavor during this decade [para. 3]. (...)

We are pursuing a win-win strategy of opening-up to increase the openness of China's economy. Since joining the WTO in 2001, we have speeded up efforts to change the way of conducting foreign trade, (...). China today is a fully open market economy. The opening-up policy has both benefited China's development and the well-being of its people and contributed to regional and global economic growth [para. 6]. (...)

China will continue to deepen reform and opening-up and resolutely remove institutional hurdles to increase the momentum of pursuing sustainable development [para. 14]. (Wen Jiabao, September 14, 2011)

Deregulation of the market lessens the government function in controlling trade. Hence, for the globalists, 'restricting trade' is 'exactly the wrong thing to do' (24). Trade organizations, such as the WTO become the player and act as a resource of legitimizing the free trade. The WTO is committed to the global free trade through 'reform' and the reduction of 'tariffs', taxes and 'other barriers' from trade. The globalist point of view is that government interventions in economy, such as setting the tariffs on import and export, can limit the progress of global economic development.

Governments should, therefore, interfere in the conduct of trade as little as possible (25). If present, the engagement of the government is merely to facilitate the process of globalization for example free movements of capital (Fairclough, 2006) and provision of infrastructures. Altogether extracts (22)-(27) indicate that the globalists internalize the neoliberal ideology through the notion of liberalizing market ('liberalize world trade', 'the elimination of trade distortions and barriers'), eliminating government capital controls ('too much government involvement in the market'), reducing tariffs ('cut tariff', 'removed mom-tariff measures', 'remove institutional hurdle'), privatizing public services, and weakening regulations that protect labors. Governments by making use of international agencies-IMF, WTO-naturalize this discourse through universalization that global economy is inevitable and it is essentially materialized for example by 'liberalization' of 'trade' and 'investment'.

The powerful WTO has approved global competition and unregulated market as the best opportunity to create the equal prosperity of the world's population. This new governing regime increasingly provides a major general control over every aspect of the lives of the majority of the world's people. What not said is that the control is not for the economic well-being of nations as the claim is often made but rather on the enhancement of the power and wealth of the world's largest corporations and financial institutions. The approval of the Uruguay and other further WTO's agreements has institutionalized a global economic and political structure that makes every government increasingly dependent on a baffling system of transnational governance designed to boost corporate profit (Wallach \& Sforza, 1999), often with complete ignorance of social and environmental consequences. The WTO and other trade agreements have moved away beyond their traditional roles of 'setting quotas and tariffs'. Now such institutions set new and unprecedented controls over democratic governance. Erasing national laws and economic boundaries to foster capital mobility and free trade has led General Motors, Shell and other 
mega-corporations to celebrate their success. The establishment of the WTO marks a momentous formalization and strengthening of their power. To the WTO and its supporting alliance, the globe is viewed primarily as a common market and capital source. Governments, laws and democracy are conceived as the irritating factors that restrict the exploitation and limit the profit (Wallach \& Sforza, 1999).

States and multinational companies shape the globalization of trade and finance through the discourse of 'opening-up'. The contexts of discourse of 'opening-up' include 'market', 'trade', 'investment' and 'development'. The word 'open' perhaps has a less provocative meaning compared to the term global; it is used in other contexts such as the domain of education, for example open university; the university that is open welcomes every person, but sounds less competitive. This is a reason why perhaps Premier Wen Jiabao seems to have preferred the term open to global. The word 'open' also suggests that there should be no secret agenda from a special state in the global economy. In other words, there must be accountability, transparency, and trusted governance between countries.

From a systemic grammar point of view (Halliday \& Matthiessen, 2014), the word 'open' can be used as a verb, such as in extract (25) and therefore it can co-occur with an inanimate colligated subject 'nations' and its predicate collocations 'market', 'trade' and 'investment'. However, the word is used as an adjective as in (27). Whether it is used as a main verb or a modifying adjective, in the discourse of globalization the word 'open' is an indicator of globalist style, part of language that embodies neoliberal economy. In fact, leaders from the U.S.A and China see neoliberalism as the tenet that encourages the world toward more 'open trade' and discursively construct it as 'trade liberalization', removal of 'mom-tariff measures', 'opening-up', and removal of 'institutional hurdles'. The clause 'But Congress should consider how freer trade affects the nation as a whole' in (23) constitutes the genuine statement of a neoliberal economic perspective. The denial 'but' challenges the outcry that 'trade liberalization creates winners and losers'. No mentions is made that uncontrolled trade liberations ruins the welfare of society, because it sets up limit to the intervention of government in economic practices and overrides democracy.

Governments and financial institutions (the World Bank and IMF) need to 'reform' their economic and political perspectives to thrive in the global economy. They thus need to be adhered to competitive and open market. It is so open and interconnected that there is no possibility of turning back. In the interconnected global economy, market and trade require liberty policies. We can refer to this as "forced democratic" global economy. Nations including developing economies need to follow the discourse as a powerful strategy, for example, for fulfilling an essential term and condition for receiving loans from the World Bank, joining the WTO or attracting Foreign Direct Investments. The discourse of globalization is translated into the discourse of 'economic development' through open and competitive market. The globalists do not argue that uncontrolled trade competition leads to monopoly of the global economy by the (multinational) giants, leaving out basic universal rights such as food security and equal access to resources. For them, the government involvement in regulating market has to be reformed for the sake of so-called free market while in fact they are fostering a dominant nation's progress and its hegemonic corporations.

\section{Concluding Remark}

This article has attempted to unravel the sort of ideology that the texts on globalization are potentially capable of (re)constructing. From the analysis of the extracts from two text types, it demonstrates that the texts on globalization discursively construct new capitalism and neoliberalism. The construction of these economic ideologies is manifested through universalization of the operational beliefs and values of the global economy. These fundamental values and beliefs are instilled through discursive elements: trade liberalization, capital flows, global competition and reduction of governments' regulations in trade, among others.

The discussion above socially and politically implies two things. First, new capitalism is a form of capitalism that has attempted to dominate the power in the global economy, politic and other social aspects of human life. It makes use advances of technology, management expertise, telecommunication, and knowledge economy for its modus operandi. Advances in technology are seen to have changed the way people work, communicate and do businesses. The internet for example is claimed to have changed the way people work in many aspects. Unfortunately, the advances in telecommunication technology have not benefited the world society as a whole. They are still more accessible to communities in the developed world. People in LDCs cannot easily have an access to telecommunication technologies. As a result, the manifest of global economy is partly still a dream for those people, especially when these people are forced to compete to boost the economic growth. Politically, since not every state is capable of competing in the marketplace, the social-Darwinism philosophy of "survival of the fittest" emerges and Neitzscheist "will to power" is inevitable.

Second, neoliberalism is the political project (and ideology) that attempts to achieve the full development of new economies (Fairclough, 2002). Neoliberalist sees globalization as an inexorable economic logic in the 
contemporary capitalist society. The neoliberal value system is a manifestation of the economic, political, and social agenda that is promoted as a tenet by the WTO, IMF, World Bank, leaders of state and leading economists. Neoliberal proponents contend that modern economy is materialized in the forms of transcendental free trade, investment liberalization and knowledge economy; the government involvement in the economy needs to be placed at the minimum. By means of these economic practices, a social change is expected in the contemporary global society. Sadly, the change has yet been equally materialized. In short, globalization is real; however, people need to be aware of both its discursive and material processes, so that the advantages of globalization are fairly distributed to all layers of the world society.

\section{References}

Althusser, L. (1971). Ideology and ideological state apparatuses. In L. Althusser (Ed.), Lenin and philosophy and other essays (pp. 85-126). London: New Left Books.

Amin, S. (1997). Capitalism in the age of globalization. London: Zed.

Bhaskar, R. (1986). Scientific realism and human emancipation. London: Verso.

Blomaert, J. (2005). Discourse: A critical introduction. Cambridge: Cambridge University Press.

Bourdieu, P., \& Wacquant, L. (2001). New liberal speak: notes on the new planetary vulgate. Radical Philosophy $105,2-5$.

Chang, H. J. (2011). 23 Things they don't tell you about capitalism. London: Penguin.

Charlesworth, A. (2014). Digital marketing: A practical approach (2nd ed.). London: Routledge

Chiapelo, E., \& Fairclough, N. (2002). Understanding the new management ideology: a Transdisciplinary contribution from critical discourse analysis and new sociology of capitalism. Discourse \& Society, 13(2), 185-208. http://dx.doi.org/10.1177/0957926502013002406

Chouliaraki, L., \& Fairclough, N. (1999). Discourse in late modernity: Rethinking critical discourse analysis. Edinburgh: Edinburgh University Press.

Eagleton, T. (1991). Ideology. London: Verso.

Fairclough, N. (1992). Discourse and social change. Cambridge: Polity Press.

Fairclough, N. (2001). Language and power (2nd ed.). London: Longman.

Fairclough, N. (2002). Language in new capitalism. Discourse \& Society, 13(2), 163-166. http://dx.doi.org/10.1177/0957926502013002404

Fairclough, N. (2003). Analyzing discourse: Textual analysis for social research. London: Routledge.

Fairclough, N. (2006). Language and globalization. London: Routledge.

Fairclough, N., \& Thomas, P. (2004). Discourse of globalization and globalization of discourse. In D. Grant (Ed.), The Sage handbook of organizational discourse (pp. 380-396). London: Sage.

Giddens, A. (2000). Runaway world: How globalization is reshaping our lives. New York, NY: Routledge.

Gramsci, A. (1971). Selections from the prison notebooks. New York, NY: International Publishers.

Halliday, M. A. K., \& Matthiessen, C. (2014). Halliday's introduction to functional grammar (4th ed.). London: Routledge.

Jessop, B. (2004). Critical semiotic analysis and cultural political economy. Critical Discourse Studies, 1(2), 154-174. http://dx.doi.org/10.1080/17405900410001674506

Kanter, R. M. (2001). Evolve! Boston, MA: Harvard Business School Press.

Kiely, R. (2000). Globalization: From domination to resistance. Third World Quarterly, 21(6), 1059-1070.

Klein, N. (1999). No logo: Taking aim at the brand bullies. New York, NY: Picador.

Laclau, E., \& Mouffe, C. (2001). Hegemony and socialist strategy (2nd ed.). London: Verso.

Lecercle, J. (2009). A Marxist philosophy of language (G. Elliott, Trans.). Chicago: Haymarket Press.

$\mathrm{Li}$, J. (2009). Intertextuality and national identity: Discourse of national conflicts in daily newspapers in the United States and China. Discourse \& Society, 20(1), 85-121. http://dx.doi.org/10.1177/0957926508097096

Luke, A. (2002). Beyond science and ideology critiques: Developments in critical discourse analysis. Annual Review of Applied Linguistics, 22, 96-110. http://dx.doi.org/10.1017/S0267190502000053 
McLellan, D. (1986). Ideology. London: Open University Press.

Ohmae, K. (1994). The borderless world: Power and strategy in the global marketplace. London: Harper Collins.

Pêchuex, M. (1982). Language, semantics and ideology. New York, NY: St Martin's Press.

Robertson, R. (1992). Globalization: Social theory and global culture. London: Sage.

Scholte, J. A. (1997). Global capitalism and the state. International Affairs, 73(3), 427-452.

Thompson, J. B. (1984). Studies in the theories of ideology. Berkeley, CA: University of California Press.

van Dijk, T. A. (1998). Ideology: A multidisciplinary approach. London: Sage.

Vološinov, V. N. (1973). Marxism and the philosophy of language. New York, NY: Seminar Press.

Wallach, L., \& Sforza, M. (1999). The WTO: Five years of reasons to resist corporate globalization. New York, NY: Seven Stories Press.

Williams, R. (1983). Keywords (Revised ed.). Oxford: Oxford University Press.

Zheng, S. (2014). A critical discourse analysis of financial remarks: A case study. International Journal of English Linguistics, 4(5), 105-116. http://dx.doi.org/10.5539/ijel.v4n5p105

\section{Appendix A}

\section{The 14 Texts on Globalization Chosen for Sources of Data}

\begin{tabular}{|c|c|c|}
\hline Date & Source/Author & Topic \\
\hline June 07,2005 & $\begin{array}{l}\text { Washington Post, Op-Ed by } \\
\text { Clyde Hufbauer \& Paul L. E. } \\
\text { Grieco }\end{array}$ & The Payoff from Globalization \\
\hline January 25, 2006 & Speech by Zeng Peiyan & Bring Forth New Ideas and Seize Future Opportunities \\
\hline June 06, 2006 & $\begin{array}{l}\text { China Daily, Op-Ed by Le } \\
\text { Tian }\end{array}$ & 'Genghis Khan Started Globalization' \\
\hline October 26, 2006 & $\begin{array}{l}\text { Washington Post, Op-Ed by } \\
\text { Robert J. Samuelson }\end{array}$ & Capitalism's Next Stage \\
\hline April 26, 2007 & Speech by Frederic S. Mishkin & Globalization and Financial Development \\
\hline May 1, 2007 & Speech by Ben Bernanke & $\begin{array}{l}\text { Embracing the Challenge of Free Trade: Competing and } \\
\text { Prospering in a Global Economy }\end{array}$ \\
\hline February 27, 2008 & $\begin{array}{l}\text { Washington Post, Op-Ed by } \\
\text { Steven Pearlstein }\end{array}$ & Mobilization for Globalization \\
\hline July 16,2008 & $\begin{array}{l}\text { Washington Post, Op-Ed by } \\
\text { Robert J. Samuelson }\end{array}$ & A Baffling Global Economy \\
\hline November 13, 2008 & Speech by George Bush & Financial Markets and World Economy \\
\hline January 28, 2009 & Speech by Wen Jiabao & $\begin{array}{l}\text { Strengthen Confidence and Work Together for a New Round } \\
\text { of World Economic Growth }\end{array}$ \\
\hline September13, 2010 & Speech by Wen Jiabao & $\begin{array}{l}\text { Consolidate the Upward Momentum and Promote Sustained } \\
\text { Growth }\end{array}$ \\
\hline January 21, 2011 & Speech by Barrack Obama & Competing in the Global Economy \\
\hline May 20, 2011 & $\begin{array}{l}\text { China Daily, Op-Ed by David } \\
\text { Greenaway }\end{array}$ & We must Resist de-globalization \\
\hline September 14,2011 & Speech by Wen Jiabao & Promote Sound, Sustainable and Quality Development \\
\hline
\end{tabular}

\section{Copyrights}

Copyright for this article is retained by the author(s), with first publication rights granted to the journal.

This is an open-access article distributed under the terms and conditions of the Creative Commons Attribution license (http://creativecommons.org/licenses/by/3.0/). 